\title{
Samoprocjena zdravstvenog statusa i nekih aspekata kvalitete života starijih osoba s osteoartritisom koljena
}

1 Sandra Rusac Kukić

2 Silvia Rusac

3 Marko Buljevac

1 Thalassotherapia Opatija, specijalna bolnica za medicinsku rehabilitaciju bolesti srca, pluća i reumatizma

2 Studijski centar socijalnog rada Pravnog fakulteta Sveučilišta u Zagrebu

3 Studijski centar socijalnog rada Pravnog fakulteta Sveučilišta u Zagrebu

\section{Sažetak}

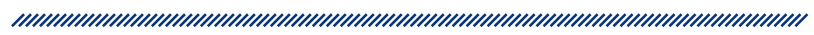

Osteoartritis koljena predstavlja važan čimbenik u nastanku tjelesnog oštećenja kod starijih osoba i utječe na funkcionalne sposobnosti osobe, a time i na kvalitetu života. Cilj ovog istraživanja bio je utvrditi postoje li statistički značajne razlike u samoprocjeni zdravlja i nekim aspektima kvalitete života starijih osoba s OA-om koljena. Istraživanje je provedeno na uzorku od 74 ispitanika starijih od 65 godina. $U$ analizi su primijenjeni validirani instrumenti: upitnik WOMAC i upitnik SF-36. Rezultati istraživanja ukazuju kako je najviša povezanost između ukupnog intenziteta pojavnosti simptoma OA-a s tjelesnim bolovima i ograničenjima u ostvarenju životnih uloga zbog tjelesnog zdravlja. Također, utvrđeno je da se ispitanici statistički značajno razlikuju u procjenama jedino prema dobi i trajanju boli, dok nisu utvrđene statistički značajne razlike prema spolu i bračnom statusu. Stoga se može zaključiti kako OA koljena utječe na samoprocjenu zdravstvenog statusa osobe i na kvalitetu života pojedinca.
Ključne riječi: osteoartritis koljena, samoprocjena zdravstvenog statusa, samoprocjena kvalitete života

Datum primitka: 15.11.2019.

Datum prihvaćanja: 15.2.2020.

https://doi.org/10.24141/1/6/1/7

Adresa za dopisivanje:

Silvija Rusac

Zelinska 7, 10000 Zagreb, Hrvatska

E-mail:srusac@pravo.hr

T: +385915468474 


\section{Uvod}

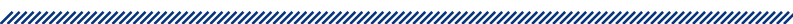

Kvaliteta života može se smatrati konceptom koji identificira što je osobi važno, nužno i zadovoljavajuće (Schippers 2010). Postoje različite perspektive o tome kako bi kvaliteta života trebala biti konceptualizirana i mjerena (Cummins 2005), od kojih je jedna kako je to „kompleksan, sintetički doživljaj zadovoljstva/nezadovoljstva životom koji nastaje svojevrsnom trajnom evaluacijom i reevaluacijom življenja i iskustva pojedinaca u različitim područjima" (Krizmanić i Kolesarić 1992: 6). Svjetska zdravstvena organizacija (2017) definira kvalitetu života kao percepciju uloge pojedinca u kontekstu kulture i vrijednosti u kojima živi te u odnosu na njegove ciljeve, očekivanja, standarde i brige. Kvaliteta života često se izjednačava $s$ pojmovima subjektivno blagostanje, zadovoljstvo životom i subjektivna kvaliteta života (Lovreković i Leutar 2010). Koncept kvalitete života obuhvaća četiri glavna područja: komponentu ponašanja (zdravlje, funkcionalna sposobnost, spoznajnu sposobnost, korištenje vremena i društveno ponašanje); psihičko zadovoljstvo (mentalno zdravlje, kognitivna procjena općeg životnog zadovoljstva, pozitivne i negativne emocije i iskustva općoj životnoj situaciji); percipiranu kvalitetu življenja (zadovoljstvo kućanstvom, susjedstvo, osobna sigurnost) i objektivnu okolinu (fizička okolina, uvjeti življenja, ekonomska situacija) (Lawton i sur. 1995; Sarvimaki i Stenbock-Hult 2000; Jaracz i sur. 2004). Petrak i sur. (2006) navode da je za procjenu kvalitete života potrebno znati koja je subjektivna važnost tih potreba za pojedinca te opseg u kojem on smatra da su te potrebe zadovoljene. Kvaliteta života može se opisati kroz dvije glavne kategorije: subjektivnu (percepcije i procjene pojedinca te njegova dobrobit) te objektivnu (mikrosocijalni čimbenici uvjeta života) (Pawłowska-Cyprysiak i sur. 2013). Schippers (2010) navodi da koncept uključuje sve domene osobnog i obiteljskog života.

Samoprocjena zdravlja, kao subjektivna mjera, povezana je s dobrobiti osobe jer obuhvaća procjenu i tjelesnoga i emocionalnoga zdravlja. Utvrđeno je da je subjektivno zdravlje za većinu osoba prvenstveno odrednica kvalitete života povezana sa zdravljem. Stoga je često uključeno, uz funkcionalnu sposobnost, među pokazatelje kvalitete života povezanih sa zdravljem (Despot Lučanin i sur. 2006). Subjektivna procjena zdravlja putem samoprocjene zdravstvenog statusa sastavni je dio epidemioloških istraživanja i istraživanja u zajedni- ci (Congdon 2001; Maslić Seršić i Vuletić 2006) jer česta primjena subjektivne procjene zdravlja reflektira važnost individualne procjene vlastitog zdravlja te ukazuje na multidimenzionalnu prirodu zdravlja (Maslić Seršić i Vuletić 2006). Pojam kvalitete života povezane sa zdravljem nastao je kao posljedica shvaćanja da je zdravlje vrlo važan, ako ne i najvažniji uvjet dobre kvalitete života (Paterson 2010). Samoprocjena zdravstvenog statusa i kvalitete života ukazuju na važnost subjektivnog doživljaja i kvalitete života neovisno o objektivnim mjerama i sastavni su dio populacijskih studija zdravlja. Nemoguće je razdvojiti bolest (kao preduvjet tjelesnog oštećenja) od osobnog i socijalnog konteksta, a jedan je od načina da se ti konteksti objektiviziraju procjena kvalitete života preko različitih dimenzija. Zdravlje kao jedan od čimbenika koji utječu na osobnu kvalitetu života te individualni doživljaj zadovoljstva životom mora biti prepoznat kao vrijedan pokazatelj stanja zdravlja populacije (Vuletić 2013).

Posljednjih desetljeća utvrđeno je kako je artritis jedan od najčešćih uzroka invaliditeta u mnogim državama (McAlindon i sur. 1992a; O’Reilly i sur. 1996). Ujedinjeni narodi, Svjetska zdravstvena organizacija, određena profesionalna udruženja i udruge pacijenata proglasile su razdoblje od 2000. do 2010. godine dekadom kostiju i zglobova, u cilju utvrđivanja „tereta” mišićno-koštanih oboljenja i poboljšanja kvalitete života (posebno zdravstvenog aspekta kod osoba s mišićno-koštanim simptomima), ali i zbog velikih financijskih izdvajanja namijenjenih liječenju bolesti povezanih s ovim aspektom zdravlja (Ringdahl i Pandit 2011).

Osteoartritis (dalje u tekstu $O A$ ) je najčešća reumatska bolest $\mathrm{s}$ konačnim ishodom gubitka funkcije organa za kretanje. Patofiziološki proces kroničnog je karaktera s postupnim razvojem tipičnih kliničkih i radioloških znakova (Babić-Naglić 2005). Predstavlja kroničnu, degenerativnu reumatsku bolest, najčešće multifaktorijalne etiologije. Etiološki, OA se može podijeliti na primarni i sekundarni. Primarni OA multifaktorska je bolest nepoznata uzroka koja uključuje biokemijske, metaboličke, endokrinološke čimbenike i čimbenike koji mogu biti modificirani dobi, spolom, nasljednim i bihevioralnim utjecajem (Grazio i Balen 2009). Sekundarni OA povezan je s poznatim događajem ili bolešću, a najčešće nastaje zbog promijenjenih mehaničkih odnosa (npr. loše srasli ili intraartikularni prijelomi, slabost mekih tkiva, kongenitalne ili razvojne anomalije, metaboličke, endokrinološke, neuropatske, koštane, upalne neinfektivne reumatske bolesti, nakon infekcije zgloba, krvne diskrazije) (Bearly 2006, prema Kosor i Grazio 2013). OA se može 
pojaviti na bilo kojem zglobu, ali češći je u zglobovima prstiju šaka, kuku, koljenu, zglobovima vratne i slabinske kralježnice te u prvom metatarzofalangealnom zglobu. Shodno lokalizaciji i zbog razlika u prirodnom tijeku između zglobova / zglobnih etaža, najnepovoljnije posljedice na funkcionalni status ima OA kuka i koljena (Felson i sur. 2000; Grazio i sur. 2010). OA pogađa 33,6 \% osoba starijih od 65 godina. Godišnja incidencija konzultacija za simptomatski osteoartritis koljena (dalje OA koljena) procjenjuje se na 0,5\% ukupnog broja osoba u dobi većoj od 55 godina, a $1 \%$ u onih u dobi većoj od 70 godina (Peat i sur. 2001). Klinička su obilježja OA-a koljena bol, zakočenost zglobova pri prvim pokretima nakon mirovanja i smanjenje obima pokreta zgloba (Peterson i Jacobson 2002; Berry i sur. 2010; Dekker i sur. 2009; Rubbin 2005). OA koljena ima negativni utjecaj na medicinski aspekt kvalitete života (Farr i sur. 2013). Oko $80 \%$ osoba s OA-om koljena ima određena ograničenja u kretanju, $25 \%$ ne može sudjelovati u dnevnim aktivnostima dok ih $11 \%$ treba pomoć u osobnoj njezi (Centers for Disease Control and Prevention 2010). Procjenjuje se kako $15 \%$ osoba u općoj populaciji starijih od 55 godina ima ograničene aktivnosti zbog boli u koljenu koja je prisutna gotovo svakodnevno (McAlindon i sur. 1992b), dok je 14 \% ispitanika u istraživanju koje su proveli O'Reilly i sur. (1996) navelo svakodnevnu prisutnost boli koljena. Duncan i sur. (2008) uz bol i funkcionalne sposobnosti analizirali su i radiografsku progresiju koljena zahvaćenog promjenama povezanim s OA-om na uzorku od 819 osoba starijih od 50 godina. Intenzitet boli bio je analiziran upitnikom WOMAC, a radiografski nalazi Kelgren-Lawrenceovim upitnikom. Funkcionalna sposobnost bila je analizirana preko sljedećih parametara: tolerancije na hod, penjanja uz stube i silaženja niz njih, pokretljivosti u oboljelom koljenu i gruboj mišićnoj snazi ekstenzora koljena. Zaključuju da postoji povezanost između težine radiografskih promjena, jačine boli $s$ jedne i funkcionalne ograničenosti s druge strane. Lo i sur. (2001) kreirali su instrument za procjenu kvalitete života osoba s OA-om ramena (WOOS) koji je uključivao sljedeće četiri domene: bol i tjelesni simptomi, sport, funkcionalnost u aktivnostima slobodnog vremena i posla, obavljanje aktivnosti svakodnevnog života i emocionalno funkcioniranje.

Vezano uz osobe $s$ tjelesnim oštećenjem, u koje ulaze i osobe s OA-om koljena, mogu se povezati rezultati istraživanja o tjelesnom oštećenju i kvaliteti života. Rezultati istraživanja koje su proveli Bakula Anđelić i sur. (2011) pokazuju da su bračni status, radni status, procjena zadovoljstva primanjima i uvjeti stanovanja soci- odemografske varijable koje utječu na procjenu kvalitete života kod osoba s tjelesnim invaliditetom. Jedan je od rezultata istog istraživanja da su osobe u braku manje zadovoljne kvalitetom života negoli samci, nezaposleni procjenjuju kvalitetu života nižom, kao i osobe koje procjenjuju svoje prihode nižima te naposljetku da osobe koje žive u većim, bolje uređenim stambenim prostorima i njihovi su vlasnici su procjenjuju kvalitetu života boljom. Rezultati istraživanja koje su proveli Pawłowska-Cyprysiak i sur. (2013) o kvaliteti života s tjelesnim invaliditetom pokazuju nisku procjenu kvalitete života ispitanika, s time da izrazito nezadovoljavajućom procjenjuju zdravlje i vlastite funkcionalne sposobnosti, dok domene kvalitete života koje se odnose na socijalne i ekonomske, duhovnost, mentalno zdravlje i obitelj procjenjuju zadovoljavajućima. Istraživanje s osobama koje imaju OA koljena ukazuje da socijalna podrška utječe na kvalitetu života u zdravstvenoj domeni: češća druženja s drugima povezana su s boljom tjelesnom funkcionalnošću, zdravstvenim stanjem, mentalnim stanjem i vitalnošću (Ethgen i sur. 2004). Oni koji su zadovoljniji socijalnom podrškom (i imaju je) procjenjuju kvalitetu života boljom. Rezultati istraživanja koje su proveli Mockevičienè i Savenkovienè (2011) ukazuju da osobe s tjelesnim invaliditetom koje su uključene u sportske aktivnosti procjenjuju veće zadovoljstvo životom, zdravlje procjenjuju boljim te bolje prihvaćaju vlastiti invaliditet.

\section{Cilj istraživanja}

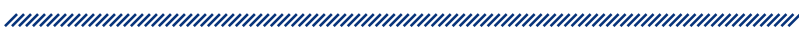

Cilj istraživanja bio je dobiti uvid u samoprocjenu intenziteta bolova, zakočenost i fizičke funkcije te s njima povezane određene aspekte kvalitete života starijih osoba s OA-om koljena. U skladu s time, postavljeni su sljedeći istraživački problemi:

1. Ispitati povezanost između rezultata na podljestvicama upitnika WOMAC i SF-36.

2. Ispitati razlike između nekih sociodemografskih obilježja (spol, bračni status, dob) i zdravstvenog statusa (komorbiditet oboljenja, trajanje boli) starijih osoba s OA-om koljena s obzirom na samoprocjenu intenziteta bolova, zakočenosti i fizičke funkcije (WOMAC). 


\section{Metodologija}

\section{Ispitanici}

Anketno istraživanje provedeno je u Klinici za liječenje, rehabilitaciju i prevenciju bolesti srca i krvnih žila u Opatiji tijekom 2018. godine. Kod svih ispitanika postavljena je dijagnoza OA-a zgloba koljena na osnovi kriterija koje je utvrdio American College of Rheumatology (Altman i sur. 1986; Bellamy i sur. 1997; Wu i sur. 2005). $\mathrm{U}$ istraživanju su sudjelovale 74 osobe starije životne dobi $(71,47 \pm 6,99$ godina), od je čega $79,7 \%$ ispitanica i $20,3 \%$ ispitanika. Prema postignutom stupnju obrazovanja, 40,5 \% ima završeno srednjoškolsko obrazovanje, 43,2 \% visokoškolsko, dok su ostali završili osnovnu školu. U vlastitom kućanstvu živi 97,3\% ispitanika. Prema sastavu kućanstva, s partnerom živi $61,6 \%$ ispitanika, udovaca/udovica je 27,4 \%, razvedenih 5,5\%, a neoženjenih/neudanih 5,5\%. Primarni je izvor prihoda kod većine sudionika mirovina (90,5\%). Prosječni ITM ispitanika iznosi $27,86 \pm 4,82$. U vezi s percepcijom vlastite bolesti odnosno medicinskim statusom, 46,3\% ispitanika navelo je da je u proteklih godinu dana bilo hospitalizirano zbog boli u koljenu. Navode da prosječno trajanje bolesti iznosi $11,89 \pm 10,76$ godina, pri čemu ih $29,2 \%$ navodi da im bol traje više od 10 godina, $26,4 \%$ između šest i 10 godina, 31,9 \% između jedne i pet godina, a $12,5 \%$ navodi trajanje manje od jedne godine. Kriteriji za uključivanje u istraživanje bili su: da su ispitanici stariji od 65 godina; bol u koljenu u trajanju od najmanje mjesec dana; radiološki nalaz (anteroposteriorni pravac $s$ ispruženim koljenom) koljena koji je odgovarao 2. ili 3. stupnju po Kellgren-Lawrenceovu (K/L) skoru. U istraživanju su poštivana sljedeća etička načela: upoznavanje sa svrhom i ciljem istraživanja, mogućnost prekida sudjelovanja $u$ istraživanju u bilo kojem trenutku i anonimnost. Prikupljanje podataka provodio je jedan radni terapeut kako bi se isključila mogućnost utjecaja različitoga subjektivnog pristupa pacijentu tijekom rada.

\section{Mjerni instrumenti}

Upitnik sociodemografskih obilježja konstruiran je za potrebe ovog istraživanja, a odnosi se na sljedeće varijable: dob, spol, obrazovni status, bračni status, broj članova kućanstva. Medicinski status analiziran je preko varijabli: ITM, prisutnost drugih bolesti, hospitaliza- cija zbog boli u posljednjih godinu dana i duljina trajanja boli.

The Western Ontario and McMaster Universities Arthritis Index (WOMAC) upitnik je koji zdravstveni stručnjaci često primjenjuju u svrhu evaluacije stanja/simptoma osoba s OA-om koljena i kuka (WOMAC Osteoarthritis Index 2012). Upitnik WOMAC konstruiran je za starije osobe s OA-om, pokazatelj je kliničkog intenziteta bolesti i procjenjuje bol, zakočenost i funkciju svakodnevnog života na tri odvojene podljestvice (Bellamy i sur. 1997). Sastoji se od 24 pitanja. Podljestvica boli sastoji se od pet čestica (raspon bodova od 0 do 20), podljestvica za zakočenost od dvije čestice (raspon bodova od 0 do 8 ) i 17 čestica za podljestvicu za funkcionalna ograničenja (raspon bodova od 0 do 68) pri čemu su rezultati: 0 nema; 1 - blago; 2 - umjereno; 3 - jako; 4 - ekstremno. Za procjenu intenziteta smetnji koljena upotrebljava se upitnik WOMAC (Bellamy i sur. 1988). U ocjenjivanju upitnikom WOMAC niži zbroj bodova prikazan je kao povoljniji ishod. Pitanja su se odnosila na podatke o poteškoćama pri hodu uz stube i niz njih; pri ustajanju iz sjedećeg stava; pri ulasku u krevet; pri stajanju, saginjanju, sjedenju, odmaranju; mogućnosti obavljanja lakših i težih kućnih poslova; poteškoćama pri ulasku ili izlasku iz automobila ili autobusa; pri ulasku u kadu; pri upotrebi WC-a; pri kupovini; pri obuvanju ili izuvanju čarapa. Za svaki navedeni dio upitnika WOMAC izračunavan je ukupan zbroj, a potom i prosječna vrijednost za svaki dio upitnika (Quintana i sur. 2006).

Upitnik zdravlja SF-36 (Ware i sur. 1993) sastoji se od 36 čestica, odnosno osam podljestvica: fizičko funkcioniranje (FF), ograničenja u ostvarenju životnih uloga zbog tjelesnog zdravlja (UF), tjelesni bolovi (TB), opće zdravlje (OZ), vitalnost (energija/umor) (V), socijalno funkcioniranje (SF), ograničenja u ostvarenju životnih uloga zbog emocionalnih problema (UE) i psihičko zdravlje (psihički nemir i psihološka dobrobit) (PZ). Svaka od podljestvica upitnika zahvaća fizičko odnosno psihičko zdravlje kroz jednu od četiri konceptualno različite mjere zdravlja: a) funkcioniranje na ponašajnoj razini, b) percipiranu dobrobit, c) ograničenja povezana sa socijalnim životom i ostvarenjem različitih životnih uloga te d) osobnu procjenu (percepciju) ukupnog zdravlja. Prve tri skale, FF, UF i TB, smatraju se mjerama fizičkog zdravlja, a posljednje tri, SF, UE i PZ, mjere su psihičkog zdravlja. Preostale su dvije skale OZ i V mješovite. Pojedine skale obuhvaćaju različiti broj čestica. Odgovori na svaku od čestica boduju se različito, u skladu s postojećim empirijskim normama, a s obzirom na dijagnostičku vrijednost pojedinog odgovora. Stoga se 
broj bodova zabilježen na pojedinoj podljestvici upitnika transformira u standardne vrijednosti i baždaren je na jedinstvenu skalu čiji teoretski minimum iznosi 0 , a maksimum 100 bodova. To omogućuje međusobnu usporedbu različitih manifestacija zdravlja koje mjeri ovaj upitnik. Kao mjere općega psihičkog zdravlja upotrijebit će se skale SF - socijalnog funkcioniranja, UE - ograničenja u ostvarenju životnih uloga zbog emocionalnih problema i PZ - psihičkog zdravlja. Kao mjere općeg fizičkog zdravlja upotrijebit će se skale: FF - fizičkog funkcioniranja, UF - ograničenja u ostvarenju životnih uloga zbog tjelesnog zdravlja i TB - tjelesnih bolova. Raspon bodova kreće se od 0 do 100 , pri čemu veća vrijednost odgovara boljem općem zdravlju.

\section{Obrada podataka}

Distribucija vjerojatnosti kontinuiranih varijabli ispitana je Smirnov-Kolmogorovljevim testom. U slučaju normalne distribucije primijenjeni su t-test i analiza varijance. U slučaju odstupanja od normalne distribucije primijenjen je Mann-Whitneyjev U-test ili KruskalWallisov test. Za utvrđivanje povezanosti između varijabli primijenjena je korelacijska analiza te Pearsonov koeficijent korelacije. Podaci su analizirani s pomoću statističkog programa SPSS 18.

\section{Rezultati}

\begin{tabular}{|c|c|c|c|c|c|}
\hline \multicolumn{6}{|c|}{$\begin{array}{c}\text { Tablica 1. Prikaz opisnih obilježja rezultata } \\
\text { postignutih na upitniku WOMAC te na } \\
\text { pojedinačnim podljestvicama }\end{array}$} \\
\hline & $\mathrm{N}$ & $\operatorname{Min}$ & $\operatorname{Max}$ & M & $\mathrm{SD}$ \\
\hline WOMAC OA ukupno & 53 & 5 & 85 & 50,70 & 21,68 \\
\hline WOMAC OA bol & 65 & 0 & 19 & 9,23 & 4,64 \\
\hline $\begin{array}{l}\text { WOMAC OA } \\
\text { zakočenost }\end{array}$ & 67 & 0 & 8 & 3,96 & 2,03 \\
\hline $\begin{array}{l}\text { WOMAC OA fizičke } \\
\text { funkcije }\end{array}$ & 53 & 2 & 60 & 37,11 & 16,01 \\
\hline
\end{tabular}

Kolmogorov-Smirnovljev test na podljestvicama pokazuje normalno distribuiranje rezultata $\left(\mathrm{K}-\mathrm{S} \mathrm{z} \mathrm{z}_{1}=0,772\right.$; $\left.\mathrm{K}-\mathrm{S} \mathrm{z}_{2}=1,089 ; \mathrm{K}-\mathrm{S}_{3}=0,802 ; \mathrm{p}>0,01\right)$, što znači da se mogu računati parametrijski testovi za utvrđivanje značajnosti razlika među skupinama sudionika (t-test, ANOVA).

Ukupan WOMAC indeks iznosi 50,70 $\pm 21,68$. Teorijski raspon na ukupno 24 čestice iznosi od 0 do 96 , pri čemu niže vrijednosti ukazuju na odsutnost stanja/simptoma osoba s OA-om koljena. Podljestvica boli sastoji se od pet čestica teorijskog raspona od 0 do 20 , ima indeks $9,23 \pm 4,643$. Podljestvica za zakočenost sastoji se od dvije čestice teorijskog raspona od 0 do 8 , a pokazuje prosječnu vrijednost od $3,96 \pm 2,03$. Ukupno 17 čestica podljestvica za procjenu fizičkih funkcija variraju u teorijskom rasponu od 0 do 68 , a pokazuju prosječnu vrijednost od $37,11 \pm 16,01$. Minimalni i maksimalni postignuti rezultati vidljivi su u tablici 2.

\begin{tabular}{|c|c|c|c|c|c|c|c|c|}
\hline & $\mathrm{N}$ & Min. & Maks. & M & SD & $\begin{array}{l}\text { Broj } \\
\text { čestica }\end{array}$ & $\alpha$ & $\mathrm{K}-\mathrm{S} \mathrm{z}$ \\
\hline Fizičko funkcioniranje & 49 & 0 & 90 & 36,43 & 23,54 & 10 & 0,880 & 1,098 \\
\hline $\begin{array}{l}\text { Ograničenja u ostvarenju životnih uloga zbog } \\
\text { tjelesnog zdravlja }\end{array}$ & 62 & 0 & 100 & 22,18 & 36,52 & 4 & 0,904 & $3,066^{*}$ \\
\hline $\begin{array}{l}\text { Ograničenja u ostvarenju životnih uloga zbog } \\
\text { emocionalnih problema }\end{array}$ & 64 & 0 & 100 & 47,92 & 46,71 & 3 & 0,925 & $2,280^{*}$ \\
\hline Vitalnost & 62 & 5 & 85 & 47,82 & 17,45 & 4 & 0,785 & 1,018 \\
\hline Psihičko zdravlje & 64 & 28 & 100 & 64,37 & 16,02 & 5 & 0,851 & 0,662 \\
\hline Socijalno funkcioniranje & 61 & 13 & 100 & 58,20 & 23,48 & 2 & 0,676 & 1,033 \\
\hline Tjelesni bolovi & 66 & 0 & 100 & 37,42 & 23,30 & 2 & 0,866 & 1,427 \\
\hline Opće zdravlje & 63 & 10 & 90 & 54,68 & 19,02 & 5 & 0,758 & 0,976 \\
\hline
\end{tabular}


U tablici 2 navedeni su osnovni deskriptivni pokazatelji rezultata postignutih na podljestvicama koje mjere procijenjenu kvalitetu psihičkog i fizičkog zdravlja s pomoću upitnika zdravlja SF-36. Na podljestvicama UF ograničenja u ostvarenju životnih uloga zbog tjelesnog zdravlja i UE - ograničenja u ostvarenju životnih uloga zbog emocionalnih problema Kolmogorov-Smirnovljev je test značajan ( $\left.K-S z_{1}=3,066 ; \mathrm{K}-S z_{2}=2,280 ; p>0,05\right)$, što znači da distribucije rezultata znatno odstupaju od normalne. Stoga će se u daljnjim analizama primjenjivati neparametrijski testovi za testiranje razlika među skupinama sudionika.

U tablici 3 prikazane su povezanosti između procjena intenziteta boli, zakočenosti i oslabljene fizičke funkcije kao simptoma OA-a s rezultatima samoprocijenjene kvalitete psihičkog i fizičkog zdravlja. Statistički značajni, laki do umjereni negativni koeficijenti ukazuju na povezanost većeg intenziteta bolova, zakočenosti i oslabljenih fizičke funkcije kao simptoma OA-a sa smanjenom procijenjenom kvalitetom zdravlja. Najviša je povezanost između ukupnog intenziteta pojavnosti simptoma OA-a s tjelesnim bolovima $(r=-0,550$; $p<0,01)$ i ograničenjima u ostvarenju životnih uloga zbog tjelesnog zdravlja ( $r=-0,528 ; p<0,01)$. Unatoč značajnoj povezanosti simptoma OA-a s kvalitetom fizičkog zdravlja, rezultati pokazuju da intenzitet pojavnosti simptoma OA-a nije značajno povezan s procijenjenom kvalitetom psihičkog zdravlja ( $r=-0,193, p>0,05)$. U nastavku slijedi prikaz razlika u sociodemografskim obilježjima s obzirom na podljestvice WOMAC-a.

Prema rezultatima prikazanima u tablici 4, ne postoje statistički značajne razlike u prisutnosti različitih simptoma OA-a s obzirom na spol ispitanika ( $\mathrm{t} 1=-0,39$; $\mathrm{t} 2=-0,20 ; \mathrm{t} 3=0,83 ; \mathrm{p}>0,05)$, jer $\mathrm{i}$ ispitanice $\mathrm{i}$ ispitanici $u$ jednakoj mjeri procjenjuju navedene simptome. Prema rezultatima može se zaključiti da najlošijima procjenjuju svoje fizičke funkcije povezane s obavljanjem određenih aktivnosti.

Prema rezultatima prikazanima u tablici 5 , ne postoje statistički značajne razlike u prisutnosti različitih simptoma OA-a s obzirom na bračni status sudionika $(F 1=0,56 ; F 2=0,45 ; F 3=1,57 ; p>0,05)$, jer ispitanici neovisno o bračnom statusu podjednako procjenjuju simptome.

\begin{tabular}{|c|c|c|c|c|}
\hline & $\begin{array}{l}\text { WOMAC OA } \\
\text { ukupno }\end{array}$ & WOMAC OA bol & $\begin{array}{l}\text { WOMAC OA } \\
\text { zakočenost }\end{array}$ & $\begin{array}{l}\text { WOMAC OA } \\
\text { fizičke funkcije }\end{array}$ \\
\hline Fizičko funkcioniranje & $-0,524^{* *}$ & $-0,360$ & $-0,332^{*}$ & $-0,560^{* *}$ \\
\hline $\begin{array}{c}\text { Ograničenja u ostvarenju životnih uloga zbog } \\
\text { tjelesnog zdravlja }\end{array}$ & $-0,528^{* *}$ & $-0,487^{\star *}$ & $-0,307^{*}$ & $-0,524^{* *}$ \\
\hline $\begin{array}{l}\text { Ograničenja u ostvarenju životnih uloga zbog } \\
\text { emocionalnih problema }\end{array}$ & $-0,312^{*}$ & $-0,301^{*}$ & $-0,139$ & $-0,310^{*}$ \\
\hline Vitalnost & $-0,408^{* *}$ & $-0,379^{* *}$ & $-0,201$ & $-0,415^{* *}$ \\
\hline Psihičko zdravlje & $-0,193$ & $-0,258$ & $-0,229$ & $-0,165$ \\
\hline Socijalno funkcioniranje & $-0,483^{* *}$ & $-0,460^{* *}$ & $-0,418^{* *}$ & $-0,462^{* *}$ \\
\hline Tjelesni bolovi & $-0,550^{* *}$ & $-0,494^{\star *}$ & $-0,302^{*}$ & $-0,553^{* *}$ \\
\hline Opće zdravlje & $-0,319^{*}$ & $-0,298^{*}$ & $-0,195$ & $-0,324^{*}$ \\
\hline \multicolumn{5}{|l|}{${ }^{*} \mathrm{p}<0,05 ;{ }^{* *} \mathrm{p}<0,01$} \\
\hline
\end{tabular}

\begin{tabular}{|c|c|c|c|c|c|c|}
\hline & spol & $\mathrm{N}$ & $M$ & SD & $t$ & $\mathrm{p}$ \\
\hline WOMAC OA bol & $\begin{array}{l}\text { muško } \\
\text { žensko }\end{array}$ & $\begin{array}{l}13 \\
52\end{array}$ & $\begin{array}{l}8,77 \\
9,35\end{array}$ & $\begin{array}{l}5,24 \\
4,54\end{array}$ & $-0,39$ & 0,692 \\
\hline WOMAC OA zakočenost & $\begin{array}{l}\text { muško } \\
\text { žensko }\end{array}$ & $\begin{array}{l}14 \\
53\end{array}$ & $\begin{array}{l}3,86 \\
3,98\end{array}$ & $\begin{array}{l}2,28 \\
1,98\end{array}$ & $-0,20$ & 0,841 \\
\hline WOMAC OA fizičke funkcije & $\begin{array}{l}\text { muško } \\
\text { žensko }\end{array}$ & $\begin{array}{l}11 \\
42\end{array}$ & $\begin{array}{l}40,73 \\
36,17\end{array}$ & $\begin{array}{l}14,61 \\
16,39\end{array}$ & 0,83 & 0,406 \\
\hline
\end{tabular}




\section{Tablica 5. Razlike u prisutnosti različitih simptoma OA-a s obzirom na bračni status}

\begin{tabular}{|c|c|c|c|c|c|c|}
\hline & Bračni status & $\mathrm{N}$ & $\mathrm{M}$ & SD & $\bar{F}$ & $\overline{\mathrm{p}}$ \\
\hline WOMAC OA bol & $\begin{array}{c}\text { neudana/neoženjen } \\
\text { život s partnerom } \\
\text { razveden/razvedena } \\
\text { udana/oženjen } \\
\text { udovac/udovica }\end{array}$ & $\begin{array}{c}3 \\
2 \\
4 \\
40 \\
15\end{array}$ & $\begin{array}{c}6,00 \\
7,50 \\
9,75 \\
9,23 \\
10,13\end{array}$ & $\begin{array}{l}5,56 \\
1,70 \\
4,50 \\
4,54 \\
5,31\end{array}$ & 0,56 & 0,690 \\
\hline WOMAC OA zakočenost & $\begin{array}{c}\text { neudana/neoženjen } \\
\text { život s partnerom } \\
\text { razveden/ razveden a } \\
\text { udana/oženjen } \\
\text { udovac/udovica }\end{array}$ & $\begin{array}{c}4 \\
2 \\
4 \\
39 \\
17\end{array}$ & $\begin{array}{l}3,75 \\
2,50 \\
4,25 \\
3,85 \\
4,35\end{array}$ & $\begin{array}{l}2,87 \\
3,53 \\
2,63 \\
1,88 \\
2,12\end{array}$ & 0,45 & 0,768 \\
\hline WOMAC OA fizičke funkcije & $\begin{array}{c}\text { neudana/neoženjen } \\
\text { život s partnerom } \\
\text { razveden/razvedena } \\
\text { udana/oženjen } \\
\text { udovac/udovica }\end{array}$ & $\begin{array}{c}3 \\
2 \\
4 \\
30 \\
13\end{array}$ & $\begin{array}{l}26,00 \\
18,00 \\
36,00 \\
40,77 \\
34,77\end{array}$ & $\begin{array}{l}24,88 \\
22,62 \\
17,83 \\
14,90 \\
14,74\end{array}$ & 1,57 & 0,196 \\
\hline
\end{tabular}

\begin{tabular}{|c|c|c|}
\hline \multicolumn{3}{|c|}{$\begin{array}{c}\text { Tablica 6. Povezanost između pojavnosti } \\
\text { simptoma kod starijih osoba oboljelih od } \\
\text { OA-a i dobi }\end{array}$} \\
\hline & & Dob sudionika \\
\hline \multirow{3}{*}{ WOMAC OA_bol } & $r$ & 0,174 \\
\hline & $\mathrm{p}$ & 0,165 \\
\hline & $\mathrm{N}$ & 65 \\
\hline \multirow{3}{*}{ WOMAC OA_zakočenost } & $r$ & $0,366^{*}$ \\
\hline & $\mathrm{p}$ & 0,002 \\
\hline & $\mathrm{N}$ & 67 \\
\hline \multirow{3}{*}{ WOMAC OA_fizičke funkcije } & $r$ & 0,109 \\
\hline & $\mathrm{p}$ & 0,437 \\
\hline & $\mathrm{N}$ & 53 \\
\hline
\end{tabular}

Najmlađi ispitanik imao je 66 godina, a najstariji 84. Prosječna je dob ispitanika 71,47 godina (SD = 6,99). Postoji statistički značajna, laka pozitivna povezanost između pojavnosti simptoma zakočenosti kod osoba oboljelih od OA-a i dobi $(r=0,366 ; p<0,01)$. Simptomi zakočenosti znatno su prisutniji kod osoba starije dobi, što je i očekivano. Slijedi prikaz rezultata koji se odnose na razlike u zdravstvenom statusu s obzirom na podljestvice WOMAC-a. ITM nije statistički značajno povezan s procjenom intenziteta pojavljivanja simptoma prema upitniku WOMAC $\left(r_{1}=0,222 ; r_{2}=0,044 ; r_{3}=0,181\right.$; $p>0,05)$. Slijedi prikaz utvrđenih razlika s obzirom na procijenjeno zdravstveno stanje ispitanika.

Ispitanici kao drugo oboljenje najčešće navode artritis kostiju, hipertenziju te bolesti srca i krvnih žila.

Osobe koje su navele da imaju prisutnost drugih bolesti uz OA statistički se značajno ne razlikuju od osoba koje su navele da nemaju prisutnu drugu bolest u intenzitetu pojavljivanja simptoma prema upitniku WOMAC $\left(t_{1}=-0,808 ; t_{2}=-0,311 ; t_{3}=0,172 ; p>0,05\right)$.

\section{Tablica 7. Prikaz učestalosti pojavljivanja dodatnih oboljenja kod ispitanika}

\begin{tabular}{|c|c|c|c|c|}
\hline & \multicolumn{2}{|c|}{ Navedeno } & \multicolumn{2}{c|}{ Nije navedeno } \\
\hline & $\mathrm{F}$ & $\%$ & $\mathrm{~F}$ & $\%$ \\
\hline Dijabetes & 11 & 14,9 & 63 & 85,1 \\
\hline Hipertenzija & 22 & 29,7 & 52 & 70,3 \\
\hline Artritis kostiju & 23 & 31,1 & 51 & 68,9 \\
\hline Astma & 1 & 1,4 & 73 & 98,6 \\
\hline Poteškoće sa spavanjem & 16 & 21,6 & 58 & 78,4 \\
\hline Bolesti srca i krvnih žila & 21 & 28,4 & 53 & 71,6 \\
\hline Depresija & 1 & 1,4 & 73 & 98,6 \\
\hline Nešto drugo & 18 & 24,3 & 56 & 75,7 \\
\hline
\end{tabular}




\begin{tabular}{|c|c|c|c|c|c|c|}
\hline & Istodobna prisutnost drugih bolesti & $\mathrm{N}$ & M & SD & $\mathrm{t}$ & $\mathrm{p}$ \\
\hline WOMAC OA bol & $\begin{array}{l}\text { da } \\
\text { ne }\end{array}$ & $\begin{array}{l}14 \\
43\end{array}$ & $\begin{array}{l}8,07 \\
9,23\end{array}$ & $\begin{array}{l}5,70 \\
4,30\end{array}$ & $-0,808$ & 0,423 \\
\hline WOMAC OA zakočenost & $\begin{array}{l}\text { da } \\
\text { ne }\end{array}$ & $\begin{array}{l}15 \\
42\end{array}$ & $\begin{array}{l}3,80 \\
4,00\end{array}$ & $\begin{array}{l}2,14 \\
2,13\end{array}$ & $-0,311$ & 0,759 \\
\hline WOMAC OA fizičke funkcije & $\begin{array}{l}\mathrm{da} \\
\mathrm{ne}\end{array}$ & $\begin{array}{l}10 \\
36\end{array}$ & $\begin{array}{l}37,20 \\
36,19\end{array}$ & $\begin{array}{l}18,54 \\
15,79\end{array}$ & 0,172 & 0,865 \\
\hline
\end{tabular}

\begin{tabular}{|c|c|c|c|c|c|c|}
\hline & Duljina trajanja boli & $\mathrm{N}$ & M & SD & $\mathrm{F}$ & $\mathrm{p}$ \\
\hline WOMAC OA bol & $\begin{array}{c}\text { manje od jedne godine } \\
1-5 \text { godina } \\
6-10 \text { godina } \\
\text { više od } 10 \text { godina }\end{array}$ & $\begin{array}{c}8 \\
21 \\
16 \\
18\end{array}$ & $\begin{array}{c}4,38 \\
9,67 \\
10,13 \\
9,89\end{array}$ & $\begin{array}{l}3,88 \\
4,21 \\
4,53 \\
4,68\end{array}$ & 3,66 & 0,017 \\
\hline WOMAC OA zakočenost & $\begin{array}{c}\text { manje od jedne godine } \\
1 \text { - } 5 \text { godina } \\
6-10 \text { godina } \\
\text { više od } 10 \text { godina }\end{array}$ & $\begin{array}{c}8 \\
22 \\
17 \\
18\end{array}$ & $\begin{array}{l}2,38 \\
4,05 \\
4,12 \\
4,28\end{array}$ & $\begin{array}{l}1,92 \\
1,93 \\
2,14 \\
1,99\end{array}$ & 1,85 & 0,147 \\
\hline WOMAC OA fizičke funkcije & $\begin{array}{c}\text { manje od jedne godine } \\
1-5 \text { godina } \\
6-10 \text { godina } \\
\text { više od } 10 \text { godina }\end{array}$ & $\begin{array}{c}6 \\
18 \\
12 \\
15\end{array}$ & $\begin{array}{l}12,50 \\
40,83 \\
38,25 \\
41,07\end{array}$ & $\begin{array}{c}10,21 \\
9,93 \\
17,56 \\
15,98\end{array}$ & 7,06 & 0,001 \\
\hline
\end{tabular}

Postoje statistički značajne razlike $u$ intenzitetu iskazane boli prema upitniku WOMAC s obzirom na duljinu trajanja boli $(F=3,66, p<0,05)$. Ispitanici koji imaju simptome manje od godinu dana $(M=4,38 ; S D=3,88)$ iskazuju statistički značajno manji intenzitet simptoma boli u odnosu na one kojima bol traje od jedne do pet godina ( $M=9,67 ; S D=4,21)$, od 6 do 10 godina $(M=10,13, S D=4,53)$ te više od 10 godina $(M=9,89$, $\mathrm{SD}=4,68)$. Između ostalih navedenih skupina ne postoje značajne razlike. Također su utvrđene i razlike $s$ obzirom na fizičke funkcije. Statistički se značajno razlikuju $(F=7,06, p<0,01)$ ispitanici koji imaju bolove u koljenu manje od godinu dana ( $M=12,50 ; S D=10,21$ ) u odnosu na skupine sudionika koje boluju od jedne do pet godina ( $M=40,83 ; S D=9,93)$, od 6 do 10 godina $(M=38,25 ; S D=17,56)$ te više od 10 godina $(M=41,07$; $\mathrm{SD}=15,98)$. Statistički značajne razlike među ispitanicima nisu utvrđene u intenzitetu zakočenosti prema upitniku WOMAC s obzirom na trajanje boli u koljenu. Samoprocijenjeno trajanje boli iskazano u godinama nije se pokazalo statistički značajno povezano s procjenom intenziteta pojavljivanja simptoma prema upitniku WO$\operatorname{MAC}\left(r_{1}=0,186 ; r_{2}=0,098 ; r_{3}=0,133 ; p>0,05\right)$.

\section{Rasprava}

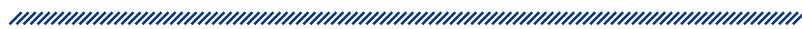

OA koljena spada u najčešća tjelesna oštećenja osoba starije životne dobi i često koegzistira s drugim bolestima i stanjima povezanima s uznapredovalom dobi, kao što su kardiovaskularne bolesti ili šećerna bolest, slabiji vid, psihosocijalni problemi (tjeskoba, depresija ili socijalna izolacija) te debljina (Grazio 2005). Prosječni ITM sudionika u ovom istraživanju iznosi $M=27,86(S D=4,82$ ), što ukazuje na prekomjernu tjelesnu masu. Naime, ako je ITM manji od 20 riječ je o pothranjenosti, 20 do 25 je idealna težina, 25 do 30 prekomjerna tjelesna masa, a više 30 ukazuje na pretilost. Unatoč neprepoznavanju točnog uzroka, rezultati nekih istraživanja ukazuju da je prekomjerna tjelesna težina jedan od najvažnijih čimbenika rizika, a i prediktor je progresije OA-a koljena. Odnos indeksa tjelesne mase (ITM) i OA-a koljena uglavnom je linearan, budući da su od velike važnosti trajanje povećanog opterećenja i dobivanje na tjelesnoj težini (Grazio i Balen 2009). Mjere deskriptivne statistike pokazale su da vrijednost WOMAC indeksa iznosi 50,70 $\pm 21,68$, što ukazuje na srednju prisutnost simptoma starijih osoba s OA-om koljena. Rezultati su pokazali da starije osobe 
s OA-om koljena iskazuju srednju prisutnost simptoma boli ( $M=9,23$; $S D=4,643$ ) i fizičkih funkcija ( $M=37,11$; $S D=16,01)$, dok najmanje iskazuju simptom zakočenosti $(M=3,96 ; S D=2,03)$. Dobiveni rezultati mogu se usporediti sa sličnim rezultatima drugih istraživanja, npr. Filipović i sur. (2014) u kojem je sudjelovalo 59 ispitanika. Prosječna dob ispitanika bila je 61,44 godina (SD $=5,07$ ), dok je prosječni ITM iznosio 27,7 . Rezultati pokazuju da je u navedenom istraživanju WOMAC boli iznosio 9,21 $(S D=3,82)$, WOMAC zakočenosti $2,41(S D=1,84)$, a WOMAC fizičke funkcije 25,31 (SD = 10,18).

Kao što je navedeno, raspon bodova na upitniku zdravlja SF-36 kreće se od 0 do 100, pri čemu veća vrijednost odgovara boljem općem zdravlju. Prosječne vrijednosti odgovora ukazuju da starije osobe najnižima procjenjuju ograničenja u ostvarenju životnih uloga zbog tjelesnog zdravlja ( $M=22,18 ; S D=36,52)$ i fizičkom funkcioniranju ( $M=36,43 ; S D=23,54)$, dok najvišim (procjenjuju da su navedenim najzadovoljnije) psihičko zdravlje $(M=64,37$; $S D=16,02)$ i socijalno funkcioniranje $(M=58,2 ; S D=23,48)$. Dobiveni rezultati ukazuju da starije osobe iskazuju emocionalno zadovoljstvo i da su izrazito zadovoljne socijalnim funkcioniranjem, a najmanje zadovoljne tjelesnim zdravljem i tjelesnim bolovima. Upravo je socijalna podrška prepoznata kao važna odrednica u kvaliteti života koja se odnosi na samoprocjenu zdravlja (Ethgen i sur. 2004). Nadalje, u istraživanju s osobama s OA-om koljena utvrđeno je kako socijalna podrška, uz stupanj snage, psihološke elemente mentalnog zdravlja, samoučinkovitost i stupanj aktivnosti, spada u čimbenike koji zaštitno djeluju na lošiji ishod, dok su kao prediktori pogoršanja identificirani dob, ITM i intenzitet boli u koljenu (Sharma i sur. 2003). Rezultati ovog istraživanja o fizičkom funkcioniranju kao području koje je procijenjeno kao manje zadovoljavajuće mogu se povezati s rezultatima istraživanja koje su proveli Leutar i sur. (2007) koji govore kako starije osobe s tjelesnim invaliditetom svoju okolinu doživljavaju neprilagođenom, gdje im osobito smetaju stubišta i povišeni pragovi. Navedeno im otežava mobilnost, kao što i OA koljena otežava mobilitet osobi.

U istraživanju Rusac (2008), u kojem je isto tako primijenjen upitnik SF-36 na reprezentativnom uzorku s 1000 osoba starijih od 65 . godina, rezultati pokazuju ipak veće prosječne vrijednosti na svakoj podljestvici upitnika, što je očekivano, s obzirom na to da je riječ o općoj populaciji starijih osoba, dok je u ovom radu fokus na kliničkom uzorku starijih osoba oboljelih od OA-a koljena.

Rezultati ovog istraživanja su pokazali da postoji povezanost između ukupnog intenziteta pojavnosti simpto- ma OA-a s tjelesnim bolovima i ograničenjima u ostvarenju životnih uloga zbog tjelesnog zdravlja. Prema IASP-u (1994), bol je neugodno senzorno ili emocionalno iskustvo praćeno stvarnim ili potencijalnim oštećenjem tkiva. Vodeći je simptom u reumatskim bolestima i važan aspekt kvalitete života. Istraživanje provedeno na starijim osobama u 38 urbanih i 12 ruralnih područja pokazalo je da $48 \%$ ispitanika svakodnevno ima bol zbog artritisa, kod 32,8 \% bol je ometala san, a u 43,1 \% artritis je bio uzrok smanjenja aktivnosti svakodnevnoga života (Jordan i sur. 2000). Croft i sur. (2005) ispitivali su intenzitet boli $\mathrm{i}$ analizirali kvalitetu života isto upitnikom SF-36 na 8995 osoba starijih od 50 godina podijeljenih u dvije skupine: oni koji su imali bol samo u koljenu i smanjenu funkcionalnu sposobnost i oni koji su osim boli u koljenu imali bol i u drugim perifernim zglobovima. U drugoj skupini ispitanika utvrđena je veća pojava anksioznosti i depresije. Ovo istraživanje ukazuje na važnost dobre evaluacije pacijenata, potrebu preciznije evaluacije boli i njezinu povezanosti s postojećim promjenama na zglobovima. Dobra procjena može u kliničkoj praksi olakšati donošenje adekvatne odluke o primjeni odgovarajuće terapije te odrediti uspješnu rehabilitaciju. Upravo rehabilitacija osoba s tjelesnim oštećenjima predstavlja uspješnost prevencije nastanka težeg stupnja invaliditeta i prevenira snižavanje kvalitete života. Istraživanje koje su proveli Leutar i sur. (2014) pokazalo je da starije osobe s invaliditetom navode najčešće svoje zdravlje (64,5\% ispitanika) kao razlog neuključenosti u zajednicu. Uključenost u zajednicu također se može smatrati indikatorom kvalitete života.

Jedan od ciljeva ovog istraživanja bio je ispitati razlike u sociodemografskim obilježjima s obzirom na podljestvice WOMAC-a. Rezultati su pokazali da ne postoje statistički značajne razlike s obzirom na spol i bračni status. Rezultati dosadašnjih istraživanja pokazuju prisutnost spolnih razlika u pojavnosti i učestalosti OA-a. Rizik obolijevanja veći je u žena, a pokazalo se da žene tendiraju težim oblicima OA-a, poglavito u menopauzi. Istraživanje koje su proveli Zakaria i sur. (2009) ukazuje da su osobe muškog spola iskazale bolji rezultat na gotovo svim dimenzijama, osobito fizičkog funkcioniranja. U istraživanju koje su proveli Alkan i sur. (2014) također su utvrđene statistički značajne razlike po spolu, jer muškarci procjenjuju svoje fizičko zdravlje boljim u odnosu na žene, kao što žene procjenjuju bol težom negoli muškarci. Glavni je simptom bol praćena oteklinom, smanjenim opsegom pokreta i posljedičnom redukcijom aktivnosti dnevnog života (Doko Guina i sur. 
2012). Ringdahl i Pandit (2011) navode da nekoliko čimbenika može povećati rizik za oboljenje, a to su: ženski spol, starija dob, pretilost (najčešći čimbenik rizika), upalne bolesti zglobova (npr. infekcija, giht, reumatoidni artritis), prethodna ozljeda koljena i zanimanja koja zahtijevaju ponavljanje savijanja koljena. Potrebno je što bolje razlučiti čimbenike koji uzrokuju ovo tjelesno oštećenje od čimbenika koji dovode do progresije bolesti. lako ne postoji općeprihvaćeni stav, u novije se vrijeme primjenjuje konceptualni pomak u smislu trenda da se termin „rizični čimbenici” sve više zamjenjuje terminom „uzroci” (Van Dijk i sur. 2010).

Rezultati ovog istraživanja pokazali su da istodobnu prisutnost drugih bolesti navodi $76,2 \%$ starijih osoba oboljelih od OA-a koljena, poput najučestalije navođenog artritisa kostiju, hipertenzije te bolesti srca i krvnih žila. Dobiveni je rezultat očekivan, s obzirom na to da su dosadašnja istraživanja potvrdila da i druge, nerijetko koegzistirajuće, kronične bolesti imaju znatan učinak na kvalitetu života osoba s OA-om (npr. Gijsen i sur. 2000). Zakaria i sur. (2009) ispitivali su kvalitetu života kod osoba starijih od 65 godina ( $N=151$ ) oboljelih od OA-a i utvrdili da je polovica ispitanika pretjerane tjelesne težine, a kod $91,4 \%$ je prisutan komorbiditet $s$ drugom bolešću (najčešće $s$ hipertenzijom), što je sukladno nalazima ovog istraživanja. Naime, prema spomenutom istraživanju, osobe s višim ITM-om i prisutnim komorbiditetom iskazale su niži rezultat na gotovo svim dimenzijama kvalitete života. Slične rezultate nudi i drugo istraživanje prema kojem je ITM ispitanika s OA-om koljena također ukazivao da in je $42 \%$ pretilo, dok su po pitanju komorbiditeta bolesti naveli kardiovaskularne $(29,2 \%)$, dišne $(14,5 \%)$ te bolesti metabolizma (11,5\%) (Salaffi i sur. 2004). Zakaria i sur. (2009) utvrdili su da postoji statistički negativna povezanost između dobi i fizičkog funkcioniranja, što indicira deterioraciju navedenog s porastom dobi. Rezultati ovog istraživanja isto ukazuju da postoji povezanost između pojavnosti simptoma zakočenosti i dobi. Rezultati istraživanja Leutar i sur. (2011) ukazuju kako se dob pokazala kao važna komponenta po pitanju neuključenosti u zajednicu, jer fizičko zdravlje ne dozvoljava uključivanje u aktivnosti starijim ispitanicima istraživanja, onima koji procjenjuju vlastiti invaliditet težim i teškim te ispitanicima kod kojih je invaliditet nastupio u kasnijoj životnoj dobi. Upravo se OA koljena može smatrati važnim indikatorom fizičkog zdravlja koji najčešće nastaje u starijoj dobi.

$\mathrm{Na}$ temelju provedene analize, ovim istraživanjem utvrđene su znatne razlike $u$ intenzitetu iskazane boli $i$ in- tenzitetu poteškoća u fizičkom funkcioniranju između osoba koje imaju bolove u koljenu manje od godinu dana u odnosu na skupine sudionika kojima bol traje od jedne do pet godina, od 6 do 10 godina te više od 10 godina. Navedeno ukazuje na moguću progresiju bolesti, koja dugoročno može negativno utjecati na kvalitetu života osoba s OA-om koljena. U istraživanju u kojem je sudjelovalo 237 osoba s OA-om kuka ili koljena i u kojem je primijenjen upitnik WOMAC zaključuje se da su loši prognostički znaci za pogoršanje funkcionalnog stanja: povećanje boli, smanjenje obima pokreta, slabljenje mišićne snage i slabije kognitivne funkcije (van Dijk i sur. 2010). Liječenje i rehabilitacija OA-a koljena multidisciplinarni su i uključuju edukaciju, opće mjere, funkcionalno liječenje i farmakoterapiju. Cilj je obrade i liječenja osobe s OA-om koljena postići kontinuitet određenog režima života, u čemu edukacija i psihosocijalna potpora imaju nezaobilaznu ulogu. Rana dijagnoza OA-a koljena, edukacija i redovito provođenje terapijskih vježbi može prevenirati ili barem odgoditi onesposobljenost (Grazio 2005). Osobu je važno upoznati s prirodom oboljenja, pojedinim rehabilitacijskim postupcima, ali ponekad i medikamentoznom terapijom. Razumijevanje i, još bolje, sudjelovanje obitelji u programu doprinos je adherenciji za program rehabilitacije. Formalna i neformalna podrška osobama s OAom u vidu edukacija i zajedničkih vježbi predstavljaju potencijalnu opciju prevencije nesposobnosti zbog OA-a koljena i alternativu nedostupnosti fizikalne terapije većem broju bolesnika. Naime, OA koljena znatno smanjuje kvalitetu života i mogućnost fizičkog vježbanja u usporedbi s osobama bez OA-a, a fizičko vježbanje i rekreacija imaju brojne pozitivne učinke ne samo na zglobove nego i na brojne druge tjelesne sustave (Grazio 2012). Na društvenoj razini nedostaju besplatni programi pod nadzorom prilagođeni osobama sa sličnim kroničnim muskuloskeletnim bolestima koji potiču svijest osoba o potrebi provođenja vježbi (Babić-Naglić 2005). Stoga su uz kliničku i radiološku procjenu ishoda rehabilitacije od iznimne važnosti i rehabilitacijska i psihosocijalna, s obzirom na to da sve navedeno utječe na kvalitetu života i samoprocjenu zdravlja osobe s OA-om koljena. Već su rezultati ranijeg istraživanja Rusac i sur. (2007) pokazali kako je samoprocjena kvalitete života starijih osoba s invaliditetom lošija od samoprocjene osoba s invaliditetom mlađe dobi. Za kraj, potrebno je naglasiti da je primjena procjene kvalitete života povezane sa zdravljem siguran put da se liječenje i evaluacija u kliničkoj praksi okrenu u većoj mjeri prema pacijentu kao osobi koja je u centru pažnje, a ne samo kao nositelju bolesti (Zdravković i sur. 2004). 


\section{Zaključna razmatranja}

OA koljena razlog je funkcionalnog ograničenja i tjelesne onesposobljenost više negoli i jedna druga kronična bolest starijih osoba, što su potvrdili i rezultati ovog istraživanja. Rezultati istraživanja pokazuju da su ispitanici zbog OA-a najnezadovoljniji ograničenjima u ostvarenju životnih uloga zbog tjelesnog zdravlja i fizičkim funkcioniranjem, dok procjenjuju da su najzadovoljniji psihičkim zdravljem i socijalnim funkcioniranjem. Navedeno dovodi do zaključka da je intenzitet pojavnosti OA-a povezan s tjelesnim bolovima i fizičkim funkcioniranjem, dok nije značajno povezan sa psihičkim zdravljem. Stoga se može zaključiti da OA koljena predstavlja važan čimbenik povezan sa smanjenom kvalitetom života osoba starije životne dobi u domenama fizičkog funkcioniranja. Premda je potvrđena povezanost ukupnih simptoma s tjelesnim bolovima i ograničenjima u ostvarenju životnih uloga zbog tjelesnog zdravlja, ono što predstavlja zaštitni čimbenik jest iskazano emocionalno zadovoljstvo, zadovoljstvo socijalnim funkcioniranjem starijih osoba te općenito psihičko zdravlje. Nadalje, rezultati ovog istraživanja također pokazuju da nema statistički značajnih razlika prema spolu i bračnom statusu s obzirom na doživljaj boli, zakočenost i fizičke funkcije. Ovakav rezultat potrebno je interpretirati s time da se navedenim testom mjere samo fizički aspekti osobe s OA-om koljena. Istraživanjem je utvrđeno da ispitanici koji imaju simptome manje od godinu dana iskazuju statistički značajno manji intenzitet simptoma i procjenjuju svoju fizičku funkcionalnost boljom negoli ispitanici s duljim trajanjem simptoma. Navedeno dovodi do zaključka kako sam tijek bolesti utječe na poimanje vlastite funkcionalnosti, kao i vrijeme od kad je utvrđen OA koljena. Ovim istraživanjem dobiven je uvid u određene aspekte procjene kvalitete života osoba s OA-om koljena, koji ukazuju na potrebu sveobuhvatnog pristupa u procjeni kvalitete života pojedinca. Može se zaključiti kako nije poželjno razdvajati fizički aspekt oštećenja od osobnog i društvenog, s time da jedan od načina dobivanja što detaljnijeg uvida u stanje osobe sveobuhvatna procjena različitih dimenzija kvalitete života putem objektivnih i subjektivnih parametara procjene. Time se može osigurati kvalitetna $\mathrm{i}$ sveobuhvatnija rehabilitacija osoba s OA-om koljena, a i prevenirati potencijalni nastanak tjelesnog invaliditeta.

\section{Reference}

1. Alkan BM, Fidan F, Tosun A, Ardıçoğlu Ö. Quality of life and self-reported disability in patients with knee osteoarthritis. Modern rheumatology, 2014, 24, 1, 166-171.

2. Altman R, Asch E, Blach D, Bole G, Borenstein D, Brandt K. Development of criteria for classification and reporting of osteoarthritis. Classification of osteoarthritis of the knee. Diagnostic and Therapeutic Criteria Committee of the American Rheumatism Association. Arthritis Rheum, 1986, 29, 8, 1039-1048.

3. Babić-Naglić $Đ$. Nefarmakološko liječenje osteoartritisa. Reumatizam, 2005, 52, 2, 40-46.

4. Bakula Anđelić M, Kovačević D, Sarilar M, Žarković Palijan T, Kovač M. Quality of life in people with physical disabilities. Collegium antropologicum, 2011, 35, 2, 247-253.

5. Bellamy N, Buchanan WW, Goldsmith $\mathrm{CH}$, Campbell J, Stitt LW. Validation study of WOMAC: a health status instrument for measuring clinically important patient relevant outcomes to antirheumatic drug therapy in patients with osteoarthritis of the hip or knee. The Journal of rheumatology, 1988, 15 (12), 1833-1840.

6. Bellamy N, Kirwan J, Boers M, Brooks P, Strand V, Tugwell $P$, Altman R, Brandt K, Dougados M, Lequesne M. Recommendations for a core set of outcome measures for future phase III clinical trials in knee, hip, and hand osteoarthritis. Consensus development at OMERACT III. J Rheumatol, 1997, 24, 799-802.

7. Berry PA, Wuka AE, Davies-Tuck ML, Wang Y, Strauss BJ, Dixon JB. The relationship between body composition and structural changes at the knee. Rheumatology, 2010, 49, 12, 2362-2369.

8. Centers for Disease Control and Prevention. Osteoarthritis. Dostupno na: http://www.cdc.gov/arthritis/basics/ osteoarthritis.htm (pristupljeno 23.5.2016.).

9. Congdon P. Health status and healthy life measures for population health need assessment: modeling variability and uncertainty. Health Place, 2001, 7, 13-25.

10. Croft $P$, Jordan $K$, Jinks $C$. Pain elsewhere and the impact of knee pain in older people. Arthritis Rheum, 2005, 52, 8, 2350-2354.

11. Cummins RA. Moving from the quality of life concept to a theory. Journal of Intellectual Disability Research, 2005, 49, 699-706.

12. Dekker J, van Dijk GM, Veenhof C. Risk factors for functional decline in osteoarthritis of the hip or knee. Curr Opin Rheumatol, 2009, 21, 5, 520-524.

13. Despot Lučanin J, Lučanin D, Havelka M. Kvaliteta starenja - samoprocjena zdravlja i potrebe za uslugama skrbi. Društvena istraživanja, 2006, 4-5, 801-817.

14. Doko Guina F, Miko M, Peloza M, Doko I. Utjecaj intraartikularne primjene hijaluronske kiseline na smanjenje 
boli u bolesnika s osteoartritisom koljena. Fiz. rehabil. Med, 2012, 1, 22-24.

15. Duncan R, Peat G, Thomas E, Wood L, Hay E, Croft P. How do pain and function vary with compartmental distribution and severity of radiographic knee osteoarthritis? Rheumatol, 2008, 47, 11, 1704-1707.

16. Ethgen $O$, Vanparijs $P$, Delhalle $S$, Rosant $S$, Bruyère $O$, Reginster JY. Social support and health-related quality of life in hip and knee osteoarthritis. Quality of Life Research, 2004, 13, 2, 321-330.

17. Farr II, Miller LE, Block JE. Quality of life in patients with knee osteoarthritis: a commentary on nonsurgical and surgical treatments. The open orthopaedics journal, 2013, 7, 619.

18. Felson DT, Lawrence RC, Dieppe PA i sur. Osteoarthritis: new insights. Part 1: the disease and its risk factors. Ann Int Med. 2000, 133, 8, 635-646.

19. Filipović K., Naumović N, Zvekić Svorcan J, Bobić B. Korelacija Womac i Lekejn indeksa kod bolesnika s osteoartrozom kolena. Medical data, 2014, 6, 1, 045-049.

20. Gijsen R, Hoeymans N, Schellevis FG, Ruwaard D, Satariano WA, Van den Bos GAM. Causes and consequences of comorbidity: a review. J Clin Epidemiol, 2005, 54, 661-674.

21. Grazio S. Debljina i zglobovi. 2012. Dostupno na: http:// moj-artritis.com/lijecenje/prehrana/142-debljina-i-zglobovi (pristupljeno 23.4.2016.).

22. Grazio S. Osteoartritis - epidemiologija, ekonomski aspekti i kvaliteta života. Reumatizam, 2005, 52, 2, 21-29.

23. Grazio S, Balen D. Debljina: čimbenik rizika i prediktor razvoja osteoartritisa. Liječnički vjesnik, 2009, 130, 22-26.

24. Grazio $S$, Ćurković B, Babić-Naglić $Đ$, Anić B. i sur. Smjernice Hrvatskoga reumatološkog društva za liječenje osteoartritisa kuka i koljena. Reumatizam, 2010, 57, 1, 36-47.

25. International Association for the Study of Pain (IASP) (1994): Classification of chronic pain. U: Mershy H, Bogduk N (ur.). IASP Task Force on Taxonomy, 2. izd. Seatle: IASP press, 209-214.

26. Jaracz K, Gustafsson G, Hamrin E. The life situation and functional capacity of the elderly with locomotor disability in Sweden and Poland according to a model by Lawton. International Journal of Nursing Practice, 2004, 10, 45-43.

27. Jordan JM, Shulamit LB, Callahan LF, Kincade JE, Konrad TR, De Friese GH. Self-reported arthritis related disruptions in sleep and daily life and the use of medical, complementary and self-care strategies for arthritis. Arch Fam Med, 2000, 9, 143-149.

28. Kosor S, Grazio S. Patogeneza osteoartritisa. Medica Jadertina, 2013, 43, 1-2, 33-45.

29. Krizmanić M, Kolesarić V. Priručnik za primjenu skala kvalitete življenja. Jastrebarsko: Naklada Slap, 1992.

30. Lawton MP, Moss M, Duhamel LM. The Quality of Daily Life Among Elderly Care Receivers. The Journal of Applied Gerontology, 1995, 14, 2, 150-171.
31. Leutar Z, Buljevac M, Babić MM. Socijalni položaj osoba s invaliditetom u Hrvatskoj. Zagreb: MOBMS, 2011.

32. Leutar Z, Štambuk A, Mijatović M. Socijalna uključenost u zajednicu starijih osoba s invaliditetom. Hrvatska revija za rehabilitacijska istraživanja, 2014, 50, 2, 118-133.

33. Leutar Z, Štambuk A, Rusac S. Socijalna politika i kvaliteta života starijih osoba s tjelesnim invaliditetom. Revija za socijalnu politiku, 2007, 14 (3), 327-346.

34. Lo IKY, Griffin S, Kirkley A. The development of a diseasespecific quality of life measurement tool for osteoarthritis of the shoulder: The Western Ontario Osteoarthritis of the Shoulder (WOOS) index. Osteoarthritis and Cartilage, 2001, 9, 8, 771-778.

35. Lovreković M, Leutar Z. Kvaliteta života osoba u domovima za starije i nemoćne u Zagrebu. Socijalna ekologija, 2010, 19, 1, 55-79.

36. Maslić Seršić D, Vuletić G. Psychometric Evaluation and Establishing Norms of Croatian SF- 36 Health Survey: Framework for Subjective Health Research. Croat Med J, 2006, 47, 95-102.

37. McAlindon TE, Cooper C, Kirwan JR, Dieppe PA. Knee pain and disability in the community. $\mathrm{Br} \mathrm{J}$ Rheumatol, 1992, 31, 189-192.

38. McAlindon TE, Snow S, Cooper C, Dieppe PA. Radiographic patterns of osteoarthritis of the knee joint in the community: the importance of the patellofemoral joint. Annals of the rheumatic diseases, 1992, 51, 7, 844-849.

39. Mockeviciene D, Savenkovienè A. Aspects of life quality of persons with physical disabilities. Social Welfare: Interdisciplinary Approach, 2012, 2, 2, 84-93.

40. O'Reilly SC, Muir KR, Doherty M. Screening for pain in knee osteoarthritis: which question? Annals of the rheumatic diseases, 1996, 55, 12, 931-933.

41. Paterson C. Quality of life measures. Br J Gen Pract, 2010, 60 (570): 53.

42. Pawłowska-Cyprysiak K, Konarska M, Żołnierczyk-Zreda D. Self-perceived quality of life of people with physical disabilities and labour force participation. International journal of occupational safety and ergonomics, 2013, 19, 2, 185-194.

43. Peat G, McCarney R, Croft P. Knee pain and osteoarthritis in older adults: a review of community burden and current use of primary health care. Ann Rheum, 2001, 60, 91-97.

44. Peterson IF, Jacobson LT. Osteoarthritis of the peripheral joints. Best Pract Clin Rheumatol, 2002, 16, 741-760.

45. Petrak O, Despot Lučanin J, Despot D. Kvaliteta starenja - neka obilježja starijeg stanovništva Istre i usporedba s drugim područjima Hrvatske. Revija za socijalnu politiku, 2006, 13, 1, 37-51

46. Quintana JM, Escobar A, Arostegui I, Bilbao A, Azkarate J, Goenaga JI, Arenaza JC. Health-Related Quality of Life and Appropriateness of Knee or Hip Joint Replacement. Archives of Internal Medicine, 2006, 166, 220-226.

47. Ringdahl E, Pandit S. Treatment of Knee Osteoarthritis. Am Fam Physician, 2011, 83, 11, 1287-1292. 
48. Rubin BR. Management of osteoarthritis knee pain. J Am Osteopath Assoc, 2005, 105, 9, 23-28.

49. Rusac S, Štambuk A, Leutar Z. Socijalna politika i kvaliteta života starijih osoba s tjelesnim invaliditetom. Revija za socijalnu politiku, 2007, 14, 3-4, 327-346.

50. Rusac S. Nasilje nad starijim osobama u obitelji. Zagreb: Pravni fakultet, Studijski centar socijalnog rada, Sveučilište u Zagrebu, 2008.

51. Salaffi F, Carotti M, Stancati A, Grassi W. Health-related quality of life in older adults with symptomatic hip and knee osteoarthritis: a comparison with matched healthy controls. Aging clinical and experimental research, 2004, 17, 4, 255-263.

52. Sarvimaki A, Stenbock-Hult B. Quality of life in old age described as a sense of well-being, meaning and value. Journal of Advanced Nursing, 2000, 32, 4, 1025-1033.

53. Schippers A. Quality of life in disability studies. Midsche Antropologie, 2010, 22, 2, 277-288.

54. Sharma L, Cahue S, Song J, Hayes K, Pai YC, Dunlop D. Physical functioning over three years in knee osteoarthritis: role of psychosocial, local mechanical, and neuromuscular factors. Arthritis Rheum, 2003, 48, 12, 3359-3370.

55. Svjetska zdravstvena organizacija. Quality of life. NY: WHO, 2017.
56. Van Dijk GM, Veenhof C, Spreeuwenberg P, Coene N, Burger BJ. Prognosis of limitation in activities in osteoarthritis of the hip or knee: a 3-year cohort study. Arch Phys Med Rehabil, 2001, 91, 1, 58-66.

57. Vuletić G. Samoprocijenjeno zdravlje i kvaliteta života u Bjelovarsko-bilogorskoj županiji: regionalne razlike i specifičnosti. Radovi Zavoda za znanstvenoistraživački i umjetnički rad u Bjelovaru, 2013, 7, 213-222.

58. Ware JE, Snow KK, Kosinski M, Gendek B. SF-36 Health Survey: Manual and Interpretation Guide. Boston: The Health Institute, New England Medical Center, 1993.

59. WOMAC OA Index. Dostupno na: http://www.auscan.org/ womac/ (pristupljeno 15.6.2016.).

60. Wu CW, Morrell MR, Heinze E, Wollaston SJ, Arnold EL, Singh R. Validation of American College of Rheumatology classification criteria for knee osteoarthritis using arthroscopically defined cartilage damage scores. Semin Arthritis Rheum, 2005, 35, 3, 197-201.

61. Zakaria ZF i sur. Health-related quality of life in patients with knee osteoarthritis attending two primary care clinics in Malaysia: a cross-sectional study. Asia Pacific Family Medicine, 2009, 8, 10, 1-7.

62. Zdravković M, Krotin M, Deljanin-Ilić M i Zdravković D. Merenje kvaliteta života bolesnika sa kardiovaskularnim oboljenjima. Med Pregl, 2010, (9-10): 701-704. 


\section{SELF-EVALUATION OF HEALTH STATUS AND SOME ASPECTS OF QUALITY OF LIFE OF OLDER PEOPLE WITH KNEE OSTEOARTHRITIS}

\section{Summary}

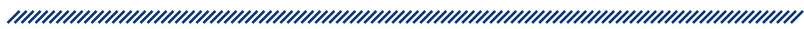

Knee osteoarthritis can results in physical disability, especially when the person is older. It affects the person's functional abilities and quality of life. The aim of this paper is to determine if there are statistically significant differences in the self- assessment of health and some aspects of quality of life of older persons with knee OA. The sample included 74 participants aged 65 years and older. WOMAC Questionnaire and SF-36 questionnaire were used for data analysis. The findings show that the highest correlation is between the overall intensity of OA symptoms with pain and inability to achieve a certain life role because of physical pain. The results show that there are statistically significant differences between age and duration of pain, while there is no statistically significant differences between gender and marital status. Knee OA has a great impact on self-evaluation of health status and some aspects of quality of life of older people. 